\title{
Assessment Perceptions and Practices in the English Department at Kabul University
}

\author{
Yar Mohamad Bahrami \\ English Department, Kabul University \\ DOI: $10.29322 /$ IJSRP.10.02.2020.p9832 \\ http://dx.doi.org/10.29322/IJSRP.10.02.2020.p9832
}

\begin{abstract}
This study investigated how instructors and students in the English Department at Kabul University perceive assessment and how it is practiced or used by the instructors. It was found out that assessment is an important factor in the teaching and learning of a language and it is perceived so by both instructors and students in the mentioned department. In addition, result of the study indicates that instructors are aware of the value of formative assessment and the students want their instructors to assess their progress and success using authentic or formative assessment.
\end{abstract}

Key words: perception, formative assessment, summative assessment, objective items

\section{INTRODUCTION}

Assessment is an important concept and some people think of testing and assessing to be the same or be synonymous terms, but they are not because assessment is an ongoing process which includes a much broader area. For instance, whenever a student answers a question, gives a comment, or tries out a new word or structure, the teacher subconsciously makes an assessment of his performance (Brown, 2004). Therefore, all works of students (from small pieces of writing to long pieces like an essay) may be assessed in different ways including assessment by the students themselves, assessment by the teacher, and possibly assessment by other students. Therefore, "a good teacher never ceases to assess students, whether those assessments are incidental or intended" (Brown, 2004, p.4).

It is worth mentioning that a test or an exam is not an assessment itself, but a test or an exam is a sub set or a part of assessment and it refers to one particular form of assessment (Leung \& Lewkowcz, 2006, p. 212). Thus, it should be noted that teaching, assessment and testing are interrelated and each one has its own role and influence in the learning of a language.

\section{Purpose of the Study}

In recent years, assessment in higher education has been the focus of increasing research and attention because it is considered an important part of a language teaching and learning. For this purpose, assessment can take different forms and can be used in a variety of ways such as to test and certify achievement, to determine the appropriate path for students to take through a differentiated curriculum, to identify specific areas of difficulty or strength for a given student (Brown, 2004). Taking these into account, this study aims to investigate the nature of assessment and perceived by the teachers and the students in the Department of English at Kabul University. It is also the goal of the study to investigate instructors' and students' beliefs and perceptions about 
effective assessment through achieving the following objective: to examine teachers' and students' perception and awareness of assessment.

To accomplish the goal of the study, the following research questions are posed:

1. What is an effective assessment?

2. How do teachers perceive assessment?

3. How do students perceive assessment?

4. What role (s) does assessment have in language learning?

\section{LITERATURE REVIEW}

\section{Assessment}

Language assessment has become a theme which is paid considerable attention and is given a high priority by educators and researchers because it is regarded as an important activity during the teaching and learning processes. According to Wach (2012), assessment includes any process that appraises an individual's knowledge, understanding, abilities or skills and it has a number functions in the process of teaching such as the selection of teaching approaches, evaluation of learners' progress, achievements, strengths and weaknesses. Similarly, Piegzik (2005) (as cited in Wach, 2012) utters, "Assessment is equally important to the teacher and the learner as it contributes to the efficiency of teaching and learning" (p.82). Assessment is, therefore, considered as the most central issue in the contemporary language education.

Furthermore, O'Connell (2010) asserts that assessment is a systematic process of collecting information about 1) what a student knows, 2) what is he able to do, and what is he learning to do? The author adds that assessment information; therefore, provides foundation for decision-making and planning for instruction and learning.

\section{Assessment Practices and Perceptions}

Belief is referred to as individual personal knowledge including experience acquired through cultural transmission and serves as implicit theories to guide thoughts and actions (Hamzah \& Wah's, 2014). They add that in a more specific view the teacher's belief was defined by Kagan (1992), Farrell and Tan (2007) as unconsciously held assumptions about students, classrooms, assessment and the academic material to be taught. On the other hand, the term classroom practice or better known as instructional practice (according to Hamzah \& Wah's, 2014) refers to what actually happens in the classrooms.

Hamzah and Wah (2014) write that several studies have strongly suggested that the relationship of the teacher's beliefs and classroom practice go hand-in-hand with equal consistency and teachers' beliefs have been found to 
influence their intended practices in the classroom. Hamzah and Wah (2014) add that there have been much work done to link teachers' beliefs to their practice, but little is known about how teachers' belief is related to their environment or context. Moreover, the mentioned authors (citing Mansour, 2007) explain that teachers' belief and practice cannot be examined out of context because it is viewed to play an important role in how beliefs are put into practice. The mentioned scholars write that as most studies indicated that educational belief in general and teachers' beliefs in particular are not "context-free", it is very much important to include contextual factors which help in this regard.

Studies in the field of language teaching and learning have established the influence of assessment on the process of a language teaching and learning. As a result of the negative consequences of current testing practices, researchers have restudied the purpose and value of the assessment in the teaching and learning processes. Due to these issues, it is pointed out that the attention should focus on the assessment as an effective tool to promote learning and as an integral part of teaching and learning. With this shift in the priorities and commitment of assessment practice, a distinction was made between summative and formative assessments (Hamzah \& Wah, 2014).

Considering context, it can be said that assessment might be perceived differently by students, teachers and even institutions in different contexts. The current classroom assessment practices of teachers in two selected institutions in Iran were investigated in a study and Assessment Reform Group (2003) reports that the way teachers perceive assessment may influence the way they teach and assess their students. A final conclusion that emerges from the findings of this study is that the role of assessor is probably among the most challenging roles the teacher performs in the contemporary foreign language classroom because it needs a considerable level of awareness, organizing skills, expertise so that the teacher can successfully carry out the dual roles of instructor and assessor.

Johnston (2003) has taken another approach and writes that he has not given an exam for more than seven years and instead he did all of his assessment "by alternative methods including portfolios, journals, written assignment and so on"(p.74). According to him, portfolio assessment is one of the best techniques and it is an organized collection of different pieces of work by a student that is presented in lieu of a traditional examination. This is a type of authentic assessment which is considered more effective and useful. In this regard, O'malley and Valdez Pierce (1996) write that this type of authentic assessment is a purposeful collection of work that shows the achievement or growth of a student and teaches students the value of selfassessment, editing and revision (p. 47).

Taking these points into account, I truly believe that portfolio assessment represents a huge improvement over traditional forms of assessment as observed and found out in my research courses in the English Department at Kabul University. That is, I myself use portfolio assessment and I have observed that there is growing evidence that a portfolio constitutes an effective assessment tool and help students in learning and improving.

Furthermore, Xioa and Carless (2013) report findings of a study in which students' perspectives on assessment were reported. The students perceive, "Their [students'] focus is on achieving a satisfactory numerical score so that they may engage in strategic behaviors. For example, the test designers [want to have] students write for communicative purpose, [but] students are mainly interested in aspects of writing that would help them achieve 
a better score and neglect the development of skills to write communicatively" (p.6). Similarly, Cohen (2001) acknowledges that students often perceive the test as a threat to their competence with the fear that they will not do well. In this regard, Cohen reports findings of Sohammy's (1985) survey of EFL teachers and students in Israeli public schools in which misuses of tests were observed or found out. In this regard, Cohen (2001) reports, "Tests were used as punishment because no one did the homework; the tests were the only measure for grading; tests did not reflect what was taught and the tests were returned with lack of corrections and explanations" (p.515).

\section{METHODOLOGY}

\section{Subjects}

The following two groups of subjects participated in the study: (1) instructor participants, and (2) student participants.

The instructor participants are seven instructors who teach in the English Language and Literature Department at Kabul University. Three of them are females and four of them are males. Four of them have graduate level (M.A.) qualification and three of them have undergraduate level (B.A.) education. Six of these participants are 25-30 years old and one of them is 42-47 years old. They teach English in the English Department and ESP in sub departments in other faculties or colleges at Kabul University. Their teaching experience in the Department of English varies. One of them has been teaching in this department for more than 15 years; three (3) of them have been teaching here for five years and three (3) of them have been teaching for one year. They teach different levels or classes in this department. That is, some of them teach freshman and sophomore students and some teach junior classes. The courses they teach are linguistics, composition and listening/speaking.

Another group of participants is fifty eight (58) undergraduate students in the English Language and Literature Department at Kabul University. They come from different parts of Afghanistan. Thirty two of them are males and twenty six of them are females and their ages are between 18 and 25 years. They are students in different classes or levels. That is, fifteen of them are fourth year students, eleven of them are third year students, twelve of them are second year students and twenty of them are first year students.

\section{Materials}

As the study seeks to explore on assessment practices and perceptions, the following two types of data collection instruments/ questionnaires were used in this study:

Task 1 (for instructors)-Assessment Practice and Perception

The focus of this task was as to investigate instructors' practices and perceptions about assessment. The task/questionnaire contained 12 different questions on the value and use of assessment and its aim was to find out how and what types of the assessment the instructors use and what they know about the role of assessment.

Task 2 (for students) - Assessment Perceptions

This task was a more interactive one and was used to measure students' perceptions and opinions about assessment. This tool was also used to investigate learners' preferences with regard to (1) quizzes, (2) midterm and final examinations and (3) the reasons behind their preferences and their association with the learners' 
learning strategies and the learning materials they studied. This task contained 13 closed-ended or yes/no questions. For each question the participants were expected to choose "Yes" or "No" based on their perception/belief and taking the effectiveness of that type of assessment into consideration.

\section{Data Collection}

The data were collected when all research protocols for human subjects were followed in the design and application of the study. That is, approval for the study was obtained and consent was obtained from the subjects and they were informed about the goal and general nature of the study as well as its potential. Participation was voluntary and all participants were given the option to withdraw from the study at any time they wanted. The participants were also informed that their information would be kept confidential and would not be disclosed to anyone without their permission and will only be used in this study. The length of time for completing the tasks was not limited.

\section{FINDINGS AND DISCUSSION}

\section{Introduction}

In this study, assessment is used to encompass both test/exam and other assessment approaches, but testing or exam is used to refer to the traditional exams usually given to students as an assessment. The term exam that appears in this paper refers to the traditional pen and paper written exams in the form of midterm and final exams used as the major part of examination history at Kabul University as well as in other settings in Afghanistan. The results are analyzed considering assessment practices and perceptions of instructors and assessment beliefs/perceptions of the students.

\section{Instructors' Perception and Practices}

Instructors' assessment beliefs and practices in this task were determined in accordance with the aim of the task. Result of the study in this regard reveals that the participants know and are aware of the value of different forms of assessment other than just midterm and final exams. Eighty six percent $(86 \%)(\mathrm{N}=6 / 7)$ of the respondents acknowledge that they have made changes in their beliefs and practices of assessment. For example, participant six (6) writes, "I thought assessment is exams, but later I understood that it is not and I now know different types of assessment". As a result of this, the notion that changes in teachers' beliefs precede changes in their assessment practices can be affirmed. It is a very positive point which indicates progress in teacher's awareness of effectiveness of assessment. According to Richards et al. (n.d.), change can refer to many things such as "knowledge, beliefs, attitudes, understanding, self-awareness and teaching practices" (p.1). Therefore, teachers' beliefs or "personal constructs" determine how they approach assessment and can affect the materials, activities and types of assessment the teachers choose for the classroom (Richards et al., n.d.). So, it can be concluded that change in the assessment practices of these instructors is an example of positive change in their beliefs about assessment and its role in language learning. 
In response to question two, $100 \%(\mathrm{~N}=7 / 7)$ of the participants agree that assessment does influence the way the students study their lessons and do their assignments. Majority of the student participants also agreed with this point as $91 \%(\mathrm{~N}=53 / 58)$ of them confirm (shown in table 2) that the classroom assessment encourages them in the way they study and do their assignments. This indicates that the effect of assessment on teachers teaching practices as well as students learning or studying is positive (Adediwura, 2012).

\begin{tabular}{|c|c|c|c|c|c|}
\hline \multirow{3}{*}{ No } & \multirow{3}{*}{ Item/Question } & \multicolumn{4}{|c|}{ Response } \\
\hline & & \multicolumn{2}{|c|}{ Yes } & \multicolumn{2}{|c|}{ No } \\
\hline & & $\mathbf{N}$ & $\%$ & $\mathbf{N}$ & $\%$ \\
\hline 1 & $\begin{array}{l}\text { Have you experienced any changes in the way you assess students } \\
\text { before now since you have involved in teaching. }\end{array}$ & 6 & 86 & 1 & 14 \\
\hline 2 & $\begin{array}{l}\text { Does assessment impact the way the students' study their lessons or } \\
\text { do the assignments? }\end{array}$ & 7 & 100 & 0 & 0 \\
\hline 3 & Do you think students' grades represent what they learned? & 2 & 29 & 5 & 71 \\
\hline 4 & Do you think it is effective if students' assess other students' work? & 7 & 100 & 0 & 0 \\
\hline 5 & $\begin{array}{l}\text { Do you think midterm and final exams are the only and effective forms } \\
\text { of assessment? }\end{array}$ & 0 & 0 & 7 & 100 \\
\hline 6 & $\begin{array}{l}\text { Do you support this idea that instructors need to have some sort of } \\
\text { background about the assessment? }\end{array}$ & 7 & 100 & 0 & 0 \\
\hline 7 & Do you think the assessment helps students in learning? & 7 & 100 & 0 & 0 \\
\hline 8 & $\begin{array}{l}\text { What do you think about alternative assessment forms such as peer } \\
\text { assessment, self-assessment, portfolio, and presentation? }\end{array}$ & \multicolumn{4}{|c|}{$\begin{array}{l}7(100 \%) \text {-all of them are useful } \\
\text { and effective }\end{array}$} \\
\hline 9 & How do you assess students? & \multicolumn{4}{|c|}{$\begin{array}{l}\text { 4(57\%) -alternative } \\
\text { assessment } \\
3(43 \%) \text {-exam, quizzes }\end{array}$} \\
\hline 10 & $\begin{array}{l}\text { Do you have any recommendations for other instructors how they } \\
\text { should assess their students? }\end{array}$ & \multicolumn{4}{|c|}{$\begin{array}{l}7(100 \%) \text {-the teachers need to } \\
\text { use alternative forms of } \\
\text { assessment }\end{array}$} \\
\hline 11 & $\begin{array}{l}\text { As an instructor, what are some dynamics that you are accountable for, } \\
\text { in terms of students' assessment results and affairs related to the } \\
\text { university? }\end{array}$ & \multicolumn{4}{|c|}{$\begin{array}{l}7(100 \%) \text {-accountable, } \\
\text { supportive, approachable }\end{array}$} \\
\hline 12 & $\begin{array}{l}\text { What is your opinion if students are informed what they will be } \\
\text { assessed on? }\end{array}$ & \multicolumn{4}{|c|}{$\begin{array}{l}6(86 \%)-\text { it is a good idea. } \\
1(14 \%)-\text { it is not needed. }\end{array}$} \\
\hline
\end{tabular}


Table 1: Instructors' Perception and Practices (Task 1)

In response to question three, $71 \%(\mathrm{~N}=5 / 7)$ of the participants accept that students' grades sometimes may not represent what they learned, but $29 \%(\mathrm{~N}=2 / 7)$ of them accept that sometimes it can be the case. It is something that $43 \%(\mathrm{~N}=25 / 58)$ of the students' participants (as illustrated in table 2) acknowledge that the grades they obtain in exams do not represent what they learned. Therefore, teachers need to know what and how much students have learned in order to monitor the effectiveness of instruction, to plan ongoing instruction, and for accountability purposes (Jabbarifar, 2009).

In regards to self-assessment and peer assessment, $100 \%(\mathrm{~N}=7 / 7)$ of the instructor participants agree that it is so useful if one student assesses the work of another student. This can be done in peer review or other similar activities inside or outside the classroom and by promoting students' skills in self/peer assessment; the students will develop their knowledge and skills (Adediwura, 2012). Similarly, 100\% (N=7/7) of the subjects agree that exams or tests are not the only forms or types of the assessment which some of them thought so before. In response to question six, $100 \%(\mathrm{~N}=7 / 7)$ of the participants accept that instructors need to be aware of the value and role of assessment. The role of the assessment in language learning is a key point which is approved by the researchers or scholars. This point is also approved by $100 \%(\mathrm{~N}=7 / 7)$ of the instructor participants in response to question seven as illustrated in the table 1 above and by 100\% (N=58/58) student participants as shown in table 2. This idea is supported by scholars such as Dodge (2009) who implies that one aim in the assessment is to help the students acquire learning of the contents or improve students' learning and grading.

Formative assessment in the forms of alternative assessment is considered more effective as it plays an important role in language learning. In this regard, $100 \%(\mathrm{~N}=7 / 7)$ of the instructor participants assert that alternative forms of assessment are effective, a notion which is also acknowledged by $91 \%(\mathrm{~N}=53 / 58)$ of the student participants as shown in table 2. Jabbarifar (2009) in this regard writes if the alternative forms of a language assessment are to be useful for classroom-based evaluation, they should be relevant or linked to instructional objectives and activities; they should be designed to optimize students' performance, and should be appropriate, relevant and interesting to students and they should be accurate, fair and ongoing.

In regards to the use of formative assessment, $57 \%(\mathrm{~N}=4 / 7)$ of the subjects confirm that they use formative or alternative forms of the assessment whereas $43 \%(\mathrm{~N}=3 / 7)$ of them have indicated that they use exams and quizzes to assess the students though in response to question 10 , all of them $(\mathrm{N}=7 / 7)$ recommend that teachers should use alternative forms of the assessment and in response to question 11, all (100\%) of them $(\mathrm{N}=7 / 7)$ agree that they feel accountable, supportive and approachable in the process of their teaching and assessment. This clearly indicates that what the instructors know or believe and what they practice is different. For instance, in response to question 5, all $(100 \%)$ of them $(\mathrm{N}=7 / 7)$ agree that only midterm and final exams are not the only effective forms of assessment, but in response to question 9, three of the participants assert that they use exams and quizzes to assess the students. In this case, it is so vital for the instructors to understand the value of classroom the assessments as they play an important role in confirming the achievement of lesson objectives (Hamzah \& Wah, 2014). In this situation, according to these authors, the instructors will be able to track their students' progress and offer them either enrichment or remedial classes. This is useful because when instructors know how students are progressing and where they are having trouble, they can use this information to make necessary changes in their instructions such as re-teaching, trying alternative instructional approaches, or offering more opportunities for practice. 
Furthermore, Adediwura (2012) utters that the teachers' assessment is related to their professional development. That is, if they practice what they know or believe, their profession will be developed and their capacities will be built. The author in this regard reports findings of Hall et al.'s (1997) study which investigated the teacher assessment practices in the classroom. In this study, the teachers claimed that the need to assess the students made them "plan their teaching in greater depth for the short, medium and longer term" (p.100). Therefore, it is important for the instructors to put their knowledge into practice so that they can develop their profession and have them be aware of the importance of keeping a continual and close attention to students' work.

Whether or not it is important and effective the students be informed on what they will be assessed as asked in question number $12,86 \%(\mathrm{~N}=6 / 7)$ of the participants agree that it is a good idea and it is better the students be informed of what they are going to be assessed. Similarly, 100\% (N=58/58) of the student participants (as shown in table 2) agree that when instructors inform them what they will be assessed on, they will do well and score higher. This finding is supported by O'malley and Valdez Pierce (1996) who assert that an assessment is successful when the students know what is expected of them.

Finally, it is to write that testing and assessment experience indicates that the teachers make decisions about assessment practices on a day-to-day basis and their decisions are influenced to a large extent by individual past testing and assessment experiences (O'malley and Valdez Pierce, 1996). For example, the research has demonstrated that learning from past experience has resulted in changes in individuals' brains; therefore, individuals can categorize what they have observed, make a decision, and carry out appropriate actions. Therefore, it is important for teachers to pause and reflect on their own past testing and assessment to guide their current and future assessment practices.

\section{Students' Perception}

Result of this task indicates that most of the participants understand and approve the value and use of different types of assessment in the form of formative assessment. For instance, in response to question twelve (12), $100 \%(\mathrm{~N}=58 / 58)$ of the participants agree and support that better and different assessment practices can help learners in the learning. This is the point which is clearly proved in other similar studies mentioned before. Also, 91\% ( $\mathrm{N}=53 / 58)$ of the participants confirm that classroom assessment encourages them in their classwork and study. A similar insight was found out in another study conducted by Dodge (2009) who implies that one aim in assessment is to help the students acquire learning of the contents or improve students' learning and grading.

In response to question three, $86 \%(\mathrm{~N}=50 / 58)$ of the participants acknowledge that they do not want or like to be assessed only through exams (midterm and final) used in the form of summative assessment which is no longer deemed an effective way of assessing students' learning and progress. Similarly, in response to question four, $43 \%(\mathrm{~N}=25 / 58)$ of the subjects confirm that the grades they gain in exams containing objective items such as multiple choice, fill-in-the blanks, true -false, explanation and other types of questions do not represent what they learned because in the cases of objective items, the students may focus on memorization of the relevant materials or books rather than learning. Such situation was also observed in Mohammad Umar and Javid's (2014) research which shows that such objective items of summative assessment, in some cases, cannot represent students' knowledge, learning and achievements and the judgment and score interpretation the teachers make based on the achieved grades will not be factual and may not help learners find out what they need to improve or learn better. 
This situation is also investigated in other researches showing that most learners do not want to take any exams and they overwhelmingly prefer ongoing assessment based on discussion and portfolio building supported by teachers' feedback and individual reflection (Dodge, 2009). It is also argued that "testing only motivates teachers and students to work towards performance goals rather than learning goals" (Adediwura, 2012, p.99).

\begin{tabular}{|c|c|c|c|c|c|}
\hline \multirow{2}{*}{\multicolumn{2}{|c|}{ Question }} & \multicolumn{4}{|c|}{ Response } \\
\hline & & \multicolumn{2}{|c|}{ Yes } & \multicolumn{2}{|c|}{ No } \\
\hline & & $\mathbf{N}$ & $\%$ & $\mathbf{N}$ & $\%$ \\
\hline 1 & $\begin{array}{l}\text { Do you think that knowing about what you will be assessed on will help } \\
\text { you score higher? }\end{array}$ & 58 & 100 & 0 & 0 \\
\hline 2 & $\begin{array}{l}\text { Do your teachers consult the students about what you will be assessed } \\
\text { on, topics or books? }\end{array}$ & 35 & 60 & 23 & 40 \\
\hline 3 & Do you like to be assessed only through midterm and final exams? & 8 & 14 & 50 & 86 \\
\hline 4 & $\begin{array}{l}\text { If you are assessed through midterm and final exams (consisting of } \\
\text { multiple choice, fill-in-the blanks, true/false, explanation and other types } \\
\text { of questions), do you think your grades represent what you learned? }\end{array}$ & 25 & 43 & 33 & 57 \\
\hline 5 & $\begin{array}{l}\text { Do you think multiple choices, yes/no, true/false, fill-in-the blanks and } \\
\text { matching questions are always effective forms of assessment? }\end{array}$ & 25 & 43 & 33 & 57 \\
\hline 6 & $\begin{array}{l}\text { Do you like to be assessed through the assessment types such as } \\
\text { projects, portfolios, journals, formal and informal questioning, etc.? }\end{array}$ & 53 & 91 & 5 & 9 \\
\hline 7 & $\begin{array}{l}\text { If you are assessed based on some of the assessment types mentioned in } \\
6 \text { above, do you think your grades represent what you learned and } \\
\text { produced? }\end{array}$ & 49 & 84 & 9 & 16 \\
\hline 8 & Do the teachers give you clear written or oral feedback? & 36 & 62 & 22 & 38 \\
\hline 9 & Do their feedbacks help you perform better in your future work? & 46 & 79 & 12 & 21 \\
\hline 10 & $\begin{array}{l}\text { Does classroom assessment encourage the way you are doing your } \\
\text { classwork or the way you study? }\end{array}$ & 53 & 91 & 5 & 9 \\
\hline 11 & Do you like peer assessment and self-assessment? & 50 & 86 & 8 & 14 \\
\hline 12 & Do you think the use of good assessment helps students in learning? & 58 & 100 & 0 & 0 \\
\hline
\end{tabular}


13 Which assessment type (s) from the following do you want your teacher to plan and use throughout the semester? Write down it/them.

Projects, self/peer assessment, journal, formal \& informal observations, teacher-student conferences, midterm and final exams, role play, portfolios, informed questioning
40(69\%): projects, self/peer assessment, , journals, formal \& informal observations, teacherstudent conferences

Table 2: Students' Perception (Task 2)

In response to question one, $100 \%(\mathrm{~N}=58 / 58)$ of the participants agree that learners' knowing about what they are going to be assessed about can help them score higher or do well in any type of assessment. This result can be supported by O'malley and Valdez Pierce's (1996) ideas who, based on the findings of many educators, write that mostly authentic assessment is successful when the students know what is expected of them, and for this reason the teachers should clearly set standards and expectations for the assessment. Therefore, this study's participants' understanding in this regard proves that teachers need to inform the students on how they (students) are assessed in the relevant course. The teachers can do this through instructional plans which specify what should be taught, and when and how it should be taught. Effective teaching requires detailed plans for an entire course, including plans for separate units and even individual lessons that comprise the course. Such plans are often referred to as the syllabus (Jabbarifar, 2009). Therefore, a well-designed syllabus provides a great deal of specific information about all aspects of instruction and it allows teachers to implement equal course appropriately and effectively and to assess it thoroughly.

Similarly, result of this study shows that students realize the value of their being informed prior to what they are assessed about and how they are assessed. The result too shows that instructors in the English Department at Kabul University do inform the students know how and on what they are assessed. As observed, this is done through providing the course syllabus containing grading scale. Sixty $(60 \%)(\mathrm{N}=35 / 58)$ of the subjects in response to question number two confirm that their instructors inform them on topics or issues they are assessed in the relevant course. This situation, for sure, will not cause anxiety and stress for the students and instead will help them learn well whereas not informing the students on what and how they are assessed and how they are graded will cause anxiety and stress and other negative feelings for the students.

In response to question eight, $62 \%(\mathrm{~N}=36 / 58)$ of the subjects acknowledge that their teachers provide feedback and in response to question nine, 79\% $(\mathrm{N}=46 / 58)$ of them accept that their teachers' feedback has been effective and has helped them do better in their next works or assignments. This clearly indicates and proves that feedback does have a positive and effective role in a language learning, especially in the correction of errors and mistakes when occur in the production of a language. Therefore, according to Hillier (2002) (as cited in Derrick and Ecclestone, 2006), the feedback given for the correction of errors and mistakes is valuable and it obviously helps in learning. The result also indicates that the quantity of feedback given by the instructors in the classroom needs to be increased and it should be given continuously for the purpose of supporting students' learning.

Rogers (as cited in Derrick and Ecclestone, 2006) asserts that without feedback, learners cannot learn and it is like a teacher is not teaching. Feedback is not always or only given by the instructors, but it can be given by 
other people involved in the teaching and learning including the students. For instance, in response to question eleven, $86 \%(\mathrm{~N}=50 / 58)$ of the participants are in favor of self-assessment and peer assessment, a notion supported by Derrick and Ecclestone (2006) (citing Hostler, 1986) who insist on the involvement of students in peer feedback because it, according to them, helps in the development of learners' autonomy.

Moreover, in response to question six, 91\% ( $\mathrm{N}=53 / 58)$ of the participants and in response to question thirteen, $69 \%(\mathrm{~N}=40 / 58)$ of the participants acknowledge that they want to be assessed through different types of assessment such as projects, products, portfolios, self/peer assessment, formal and informal observations and teacher-student conferences and the others mentioned in items 5-21 in questionnaire one. Similarly, in response to question seven, $84 \%(\mathrm{~N}=49 / 58)$ of the participants appreciate and prefer to be assessed through projects, portfolios, self/ peer assessments and other types of assessment included in 5-21 of questionnaire/task one. In this case, the participants accept that their grades or scores will represent what they learned and produced.

This indicates that participants of this study realize and acknowledge the value and importance of formative assessment which is a purposeful collection of work showing the achievement or growth of a student. In this regard, Adediwura reports findings of Iredale's (1990) study in which it was found out that in the comparison of summative assessment and formative assessment, a large majority of the students welcomed or preferred formative assessment as they believed that their actual ability may not be well reflected in a single exam, and that formative assessment practice was fairer, especially to students with test anxiety (p.102). In addition, this result is also supported by Adediwura (2012) who writes, "Researchers noted in their study that the formative assessment process encouraged students to think more, to develop skills in assessing themselves or their peers, and to learn to be collaborative learners" (p.101).

\section{CONCLUSION}

The overall findings of the study indicate that respondents (both students and instructors) support the use of the formative/authentic assessment in different forms such as portfolio, projects, self-assessment, peer assessment, oral presentation and others, and the students do not like to be assessed objectively only through exams or tests at the end of a course. It also shows that the dominant form of assessment practiced in the English Department is formative in most courses, but the use of summative assessment in the form of both objective and subjective items is also acknowledged.

The findings also indicate student respondents' preferences and perceptions of the formative assessment forms have a significant effect on their learning. In addition, the study shows that instructors in the English Department at Kabul University are aware of and use different forms of assessment (formative and summative). The findings also imply that only improved formative assessment can raise the standard of students' learning and formative assessment tools and resources deserve a serious attention of teachers and school administrators because students are one of the most important stakeholders of a "testing community" and their perceptions cannot be undervalued (Mohammad Umar \& Javid, 2014). They further write that relationship between learners' perceptions of formative assessment tasks and their learning strategies influence their learning strategies. Therefore, the instructors and the department should put more emphasis on formative assessment which should be used and treated as a teaching-learning process by all instructors. 
In conclusion, when planning assessment for the second or foreign language learning, it is important to consider the following points:

1. The teacher should use a variety of assessment techniques that clearly reflect students' progress and achievements.

2. Tests or exams should measure what they are intended to measure or what it is intended to measure (Clay and Root, 2011).

3. Different kinds of learning outcomes should be assessed in different ways. For example, knowledgerelated learning outcomes can be assessed by objective tests; attitudes are better assessed by observation.

4. Students should be involved in determining the criteria that will be used for evaluating their work. This can be part of the planning process in the beginning the course and students should know the types of assessment procedures that will be used in the course.

\section{REFERENCES}

[1] Adediwura, A. A. (2012). Teachers' Perception of School-Based Assessment in Nigerian Secondary Schools. Mediterranean Journal of Social Sciences, $3(1)$.

[2] Assessment Reform Group. (1999). The Role of Teachers in the Assessment of Learning. Nuffield Foundation.

[3] Brown, H. D. (2004). Language Assessment: Principles and Classroom Practices. New York: Pearson Education, Inc.

[4] Clay, B., Root, E. (2011). Is This a Trick Question?: A Short Guide to Writing Effective Test Questions. Kansas: Kansas Curriculum Center.

[5] Cohen, A. D. (2001). Second Language Assessment. In Celce-Murcia, M. (Ed.), Teaching English as a Second or Foreign Language ( $3^{\text {rd }}$ ed.) (pp. 515-534). USA: Heinle \& Heinle.

[6] Chen, Q. (2001). Assessment Policy Change in Relation to English Language Teaching and Learning in China: A Study of Perspectives from Two Universities. Doctoral Dissertation, Queensland University of Technology.

[7] Derrick, J., Ecclestone, K. (2006). Formative Assessment in Adult Literacy, Language and Numeracy Programmes: A Literature Review for the OECD. Centre for Learning, Teaching and Assessment Through the Lifecourse, University of Nottingham.

[8] Dodge, J. (2009). 25 Different Formative Assessments for a Differentiated Classroom. New York, USA: Scholastic Inc.

[9] Fink, L. D. (2003). A Self-Directed Guide to Designing Courses for Significant Learning. San Francisco, USA: University of Oklahoma

[10] Earl, L. (2003). Assessment as Learning: Using Classroom Assessment to Maximize Student Learning. Thousand Oaks, CA, Corwin Press.

[11] Fazlur Rahman, Rasel Babu Ashrafuzzaman. (2011). Assessment and Feedback Practices in the English Language Classroom. Journal of NELTA, 16, (1-2), 97-106.

[12] Hamzah, M.O., Wah, L.K. (2014). English for Young Learners (FLY) Teachers' Beliefs and Intended Classroom Practices with Regard to Additional Time Allocation Given to Teaching English: A Case Study. Malaysia: School of Education and Social Development, University of Malaysia Sabah.

[13] Jabbarifar, T. (2009). The Importance of Classroom Assessment and Evaluation in Educational System. Proceedings of the 2nd International Conference of Teaching and Learning.

[14] Johnston, Bill. (2003). The Morality of Testing and Assessment. In Values in English Language Teaching (pp. 61 -78). New Jersey: Lawrence Erlbaum Associates Publishers.

[15] Kral, T. (Ed.) (2004). Teacher Development: Making the Right Moves. Washington, DC: United States Department of State, Office of English Language Programs

[16] Leung, C., Lewkowicz, J. (2006). Expanding Horizons and Unresolved Conundrums: Language Testing and Assessment. TESOL Quarterly, 40(1), 211-234.

[17] Looney, J. W. (2011). "Integrating Formative and Summative Assessment: Progress Toward a Seamless System?", OECD Education Working Papers, No. 58, OECD Publishing.

[18] Mohammad Umar, Javid, C. Z. (2014). The Association between Learners' Perception of Formative Assessment Tasks and Their Reading. Proceeding of the Global Summit on Education, 155-163.

[19] O'Connell, B. (2010). Enhancing Assessment Feedback Practices in Accounting Education: Issues, Obstacles, and Reforms. Australia: Australian Learning and Teaching Council.

[20] O'malley, J. M., Valdez Pierce, L. (1996). Authentic Assessment for English Language Learners: Practical Approaches for Teachers. USA: Longman. 
[21] Richards, J.C., Gallo, P. B., Renandya, W. A (n.d.). Exploring Teachers' Beliefs and the Processes of Change. Singapore: SEAMEO Regional Language Center.

[22] Rodrigues, S. (2007). Assessing Formatively in the English Language Classroom. Journal of Research and Reflections in Education, 1(1), 1-27.

[23] Stiggins, R. J. (1991). Relevant Classroom Assessment Training for Teachers. Educational Measurement: Issues and Practice, 10(1), 7-12.

[24] Stiggins, R. J. (1992). High Quality Classroom Assessment: What does it Really Mean? Educational Measurement: Issues and Practice, $11(2), 35-39$.

[25] Wach, A. (2012). Classroom-Based Language Efficiency Assessment: a Challenge for EFL Teachers. Adam Mickiewicz University Press Poznan.

[26] Walter Lumadi, M. (2013). Challenges Besetting Teachers in Classroom Assessment: An Exploratory Perspective: $J$ Soc Sci, 34(3): 211-221.

[27] Xiao,Y., Carless, R.D. (2013). Illustrating Students' Perceptions of English Language Assessment: Voices from China. RELC Journal, 0(0) 1-22.

[28] Zhang, Z.,Burry-Stock,J.A.(2003).Classroom Assessment Practices and Teachers' Self-Perceived Assessment Skills. Applied Measurement in Education, 16(4), 323-342.

AUTHORS

First Author - Yar Mohammad Bahrami, M.A, Kabul University, yarm.bahrami@gmail.com 